\title{
Indikasi Seksio Sesarea di RSUP Prof. Dr. R. D. Kandou Manado Tahun 2017 dan 2018
}

\author{
Edwin D. Pamilangan, ${ }^{1}$ John J. E. Wantania, ${ }^{2}$ Anastasia M. Lumentut, ${ }^{2}$
}

\author{
${ }^{1}$ Program Studi Pendidikan Dokter Fakultas Kedokteran Universitas Sam Ratulangi Manado \\ ${ }^{2}$ Bagian Obstetri Dan Ginekologi Fakultas Kedokteran Universitas Sam Ratulangi Manado \\ Email: darmansaedwinpamilangan@gmail.com
}

\begin{abstract}
The prevalence of caesarian section (C-section) in Indonesia is increasing continuously from 7\% reported by SDKI 2007 to 17\% reported by SDKI 2017. This study was aimed to obtain the indication of C-section at Prof. Dr. R.D. Kandou Hospital Manado in years 2017 and 2018. This was a descriptive and retrospective study. The results showed that of total 2822 deliveries in 2017 and 2018, the C-section was performed on 694 patients (49.64\%) in 2017 and on 736 patients (51.69\%) in 2018. The most common maternal indication for Csection among 424 patients $(42.7 \%)$ was previous C-section in 107 patients $(25,23 \%)$ meanwhile the most common fetal indication among 379 patients $(38.17 \%)$ was fetal distress in 205 patients $(54.09 \%)$. Moreover, the most common combined indication among 190 patients $(19.13 \%)$ were severe preeclampsia and fetal distress in 40 patients $(21.05 \%)$. In conclusion, the most common indications of $\mathrm{C}$-section were previous $\mathrm{C}$-section, fetal distress, and of the combined indication were severe pre eclampsia and fetal distress.
\end{abstract}

Keywords: C-section, maternal indication, fetal indication, combined indication

\begin{abstract}
Abstrak: Angka persalinan seksio sesarea di Indonesia terus meningkat, dengan persentase 7\% pada SDKI 2007 menjadi 17\% pada SDKI 2017 Penelitian ini bertujuan untuk mengetahui indikasi dilakukannya seksio sesarea di RSUP Prof. Dr. R.D. Kandou Manado tahun 2017 dan 2018. Jenis penelitian ialah deskriptif retrospektif. Hasil penelitian mendapatkan dari total 2822 persalinan pada tahun 2017 dan 2018, angka kejadian seksio sesarea ialah 694 pasien $(49,64 \%)$ pada tahun 2017 dan 736 pasien $(51,69 \%)$ pada tahun 2018. Indikasi ibu sebanyak 424 pasien $(42,7 \%)$, paling banyak disebabkan oleh riwayat seksio sesarea sebelumnya sebanyak 107 pasien $(25,23 \%)$. Indikasi janin sebanyak 379 pasien $(38,17 \%)$, paling banyak disebabkan oleh gawat janin sebanyak 205 pasien (54,09\%). Indikasi gabungan sebanyak 190 pasien $(19,13 \%)$, paling banyak disebabkan oleh preeklamsi berat (PEB) dan gawat janin pada 40 pasien $(21,05 \%)$. Simpulan penelitian ini ialah pada persalinan seksio sesarea, indikasi ibu terbanyak ialah riwayat seksio sesarea; indikasi janin terbanyak ialah gawat janin; dan indikasi gabungan terbanyak ialah preeklamsi berat dan gawat janin.
\end{abstract}

Kata kunci: seksio sesarea, faktor ibu, faktor janin, faktor gabungan

\section{PENDAHULUAN}

Angka kematian ibu (AKI) di Indonesia masih terbilang cukup tinggi. Dalam MDGs terdapat sasaran pembangunan kesehatan mengenai kesehatan ibu yaitu dengan menurunkan AKI. Berdasarkan data SDKI periode 1991-2009, AKI mengalami penurunan dari 390 menjadi 228 per 100.000 kelahiran hidup, pada tahun 2012
AKI mengalami peningkatan menjadi 359 per 100.000 kelahiran hidup, dan kembali mengalami penurunan menjadi 305 per 100.000 kelahiran hidup pada tahun 2015 . Data AKI ini menunjukkan bahwa target MDGs 2015 sebesar 102 per 100.000 kelahiran hidup belum tercapai. Dalam rencana strategi kementerian kesehatan 2015-2019, Pemerintah Republik Indonesia menarget- 
kan untuk menurunkan AKI dari 359 per 100.00 kelahiran hidup, 346 menjadi 306 per 100.000 kelahiran hidup, serta menargetkan akan menurunkan angka kematian bayi (AKB) dari 32 menjadi 24 per 1.000 kelahiran hidup. ${ }^{1-3}$

Setiap hari, $830 \mathrm{ibu}$ di dunia meninggal akibat penyakit/komplikasi terkait kehamilan dan persalinan. Kemenkes RI 2010, menyatakan bahwa $25-50 \%$ kematian wanita usia subur (WUS) disebabkan oleh masalah kehamilan, persalinan, dan nifas. Komplikasi dalam persalinan merupakan indikasi persalinan dengan tindakan seksio sesarea. $^{4,5}$

Persalinan adalah proses yang terjadi dimulai dari terbukanya leher rahim hingga proses keluarnya bayi serta plasenta melalui jalan lahir (rahim). Persalinan dibagi dalam tiga jenis, yaitu: persalinan normal, persalinan buatan, dan persalinan anjuran/ induksi. Persalinan normal adalah proses persalinan yang melalui vagina (per vaginam). Persalinan anjuran/induksi terjadi setelah pemecahan ketuban, pemberian pitocin atau prostaglandin, sedangkan persalinan buatan adalah persalinan dengan bantuan tenaga dari luar misalnya dengan forceps atau seksio sesarea. ${ }^{6}$

Persalinan seksio sesarea adalah proses persalinan dengan sayatan pada dinding perut (laparotomi) dan dinding rahim. Namun demikian, tindakan seksio sesarea tidak lagi dilakukan semata-mata karena pertimbangan medis, tetapi juga termasuk permintaan pasien sendiri atau saran dari dokter yang menangani. Saat ini persalinan pervaginam dianggap sebagai persalinan yang sulit dan berisiko bagi calon ibu dan bayinya. Seiring dengan berkembangnya kecanggihan alat dibidang ilmu kedokteran kebidanan, kini tindakan operasi seksio sesarea menjadi alternatif persalinan. Di lain pihak persalinan dengan seksio sesarea mengakibatkan angka kesakitan ibu dan biaya persalinan semakin tinggi dibanding dengan persalinan normal. Angka kematian ibu akibat seksio sesarea kurang dari 1:1000 prosedur. Ancaman terbesar wanita yang menjalani seksio sesarea ialah anestesia, sepsis berat, dan serangan trombo- embolik. Yang sering menjadi morbiditas pasca tindakan seksio sesarea ialah infeksi, perdarahan dan cedera saluran kemih., ${ }^{7,8}$

Peningkatan persalinan dengan seksio sesarea disebabkan karena adanya indikasi medis dan non medis. Indikasi non medis dipengaruhi oleh usia, pendidikan, sosial budaya, dan sosial ekonomi. Adapun indikasi medis dilakukannya tindakan seksio sesarea yaitu karena partus lama, gawat janin, preeklamsia, eklamsia, plasenta previa, kehamilan kembar, solusio plasenta, panggul sempit, dan indikasi seksio sesarea sebelumnya. ${ }^{9-11}$

Data SDKI menunjukkan bahwa angka persalinan dengan seksio sesarea di Indonesia tahun 1997 sebanyak 695 dari 16.217 persalinan (4,3\%). Angka ini meningkat menjadi 921.000 kasus dari 4.039.000 persalinan $(22,8 \%)$. Persentase persalinan dengan seksio sesarea meningkat dari $7 \%$ pada SDKI 2007 menjadi 17\% pada SDKI 2017. World Health Organization (WHO) merekomendasikan bahwa angka persalinan dengan tindakan seksio sesarea tidak boleh melebihi 5-15\%. Di negara maju frekuensi seksio sesarea berkisar antara $1,5-7 \%$, sedangkan di negara berkembang proporsi kelahiran dengan seksio sesarea berkisar 21,1\% dari total yang ada., 5, 12,13

Berdasarkan latar belakang yang telah diuraikan maka penulis ingin meneliti jumlah persentase kelahiran dan indikasi dilakukannya seksio sesarea di RSUP Prof. Dr. R.D. Kandou Manado pada tahun 2017 dan 2018.

\section{METODE PENELITIAN}

Penelitian ini dilakukan di ruang rekam medik RSUP Prof. Dr. R. D. Kandou Manado pada bulan September 2019 sampai Desember 2019. Jenis penelitian ini ialah deskriptif retrospektif.

Populasi yang digunakan ialah seluruh ibu bersalin dengan seksio sesarea di RSUP Prof. Dr. R. D. Kandou Manado tahun 2017 dan 2018. Sampel penelitian ini ialah ibu hamil dengan seksio sesarea di RSUP Prof. Dr. R.D. Kandou Manado tahun 2017 dan 2018 yang memenuhi kriteria penelitian.

Penelitian ini telah mendapat persetu- 
juan dari Komisi Etik Penelitian Kesehatan RSUP Prof. Dr. R. D. Kandou Manado, dengan nomor keterangan layak etik yaitu No. 049/EC/KEPK-KANDOU/X/2019.

\section{HASIL PENELITIAN}

Penelitian ini dilakukan pada pasien dengan indikasi seksio sesarea di RSUP Prof. Dr. R. D. Kandou Manado, selama periode tanggal 1 Januari 2017 sampai 31 Desember 2018, baik yang menjalani tindakan seksio sesarea secara darurat maupun secara elektif.

Tabel 1 memperlihatkan bahwa jumlah indikasi persalinan per vaginam tahun 2017 sebanyak 704 pasien $(50,36 \%)$ dan tahun 2018 sebanyak 688 pasien $(48,31 \%)$, dengan total keseluruhan persalinan per vaginam tahun 2017 dan 2018 sebanyak 1392 pasien $(49,33 \%)$. Jumlah tindakan seksio sesarea tahun 2017 sebanyak 694 pasien $(49,64 \%)$ dan tahun 2018 sebanyak 736 pasien $(51,69 \%)$, dengan total tindakan seksio sesarea tahun 2017 dan 2018 sebanyak 1430 pasien (50,67\%). Dari 1430 pasien dengan tindakan seksio sesarea, hanya 993 pasien yang masuk dalam penelitian ini.

Tabel 2 memperlihatkan karakteritik pasien yang menjalani seksio sesarea berdasarkan usia. Frekuensi tertinggi terdapat pada usia 21-35 tahun sebanyak 631 pasien $(63,54 \%)$ dan frekuensi terendah pada usia $>46$ tahun sebanyak 2 pasien $(0,2 \%)$.

Tabel 1. Distribusi menurut jumlah jenis persalinan tahun 2017 dan 2018

\begin{tabular}{|c|c|c|c|c|c|c|}
\hline $\begin{array}{c}\text { Jenis } \\
\text { persalinan }\end{array}$ & 2017 & $\%$ & 2018 & $\%$ & Jumlah & $\%$ \\
\hline Pervaginam & 704 & 50,36 & 688 & 48,31 & 1392 & 49,33 \\
\hline Seksio sesarea & 694 & 49,64 & 736 & 51,69 & 1430 & 50,67 \\
\hline Jumlah & 1398 & 100 & 1424 & 100 & 2822 & 100 \\
\hline
\end{tabular}

Tabel 2. Distribusi frekuensi menurut usia, pekerjaan, dan pendidikan ibu

\begin{tabular}{lcc}
\hline \multicolumn{1}{c}{ Indikasi } & Jumlah & Persentase \\
\hline Usia (tahun) & & \\
$-<20$ & 120 & 12,1 \\
$-21-35$ & 631 & 63,54 \\
- 36 -45 & 240 & 24,16 \\
- >46 & 2 & 0,2 \\
Jumlah & 993 & 100 \\
Pekerjaan & & \\
- PNS & 20 & 2,01 \\
- Wiraswasta & 65 & 6,54 \\
- Ibu rumah tangga & 189 & 19,03 \\
- Pelajar/ Mahasiswa & 23 & 2,31 \\
- Lain-lain & 12 & 1,21 \\
- Tidak ada data & 684 & 68,9 \\
Jumlah & 993 & 100 \\
Pendidikan & & \\
- SD & 17 & 1,71 \\
- SMP & 32 & 3,22 \\
- SMA & 209 & 21,05 \\
- S1/S2/S3 (sederajat) & 25 & 2,52 \\
- Tidak ada data & 710 & 71,5 \\
Jumlah & 993 & 100 \\
\hline
\end{tabular}


Karakteristik pasien seksio sesarea berdasarkan pekerjaan mendapatkan frekuensi tertinggi yaitu ibu rumah tangga sebanyak 189 pasien $(19,03 \%)$, frekuensi teren-dah yaitu lain-lain sebanyak 12 pasien $(1,21 \%)$, dan sejumlah besar kasus yang tanpa data yaitu 684 pasien $(68,9 \%)$. Karakteristik tingkat pendidikan pasien menunjukkan frekuensi tertinggi yaitu SMA sebanyak 209 pasien $(21,05 \%)$, frekuensi terendah yaitu SD sebanyak 17 pasien $(1,71 \%)$, dan sejumlah besar kasus yang tanpa data yaitu 710 pasien $(71,5 \%)$.

Tabel 3 memperlihatkan bahwa indikasi yang paling berperan meningkatkan tindakan seksio sesarea di RSUP Prof. Dr. R. D. Kandou Manado tertinggi pada indikasi ibu sebanyak 426 pasien $(42,68 \%)$, disusul indikasi janin sebanyak 382 pasien $(38,28 \%)$, dan indikasi gabungan sebanyak 190 pasien $(19,04 \%)$.

Tabel 3. Distribusi frekuensi menurut indikasi yang berperan meningkatkan angka tindakan operasi seksio sesarea

\begin{tabular}{ccc}
\hline Indikasi & Jumlah & Persentase \\
\hline Ibu & 424 & 42,7 \\
Janin & 379 & 38,17 \\
Gabungan & 190 & 19,13 \\
Jumlah & 993 & 100 \\
\hline
\end{tabular}

Tabel 4 menunjukkan bahwa indikasi ibu yang memengaruhi terjadinya peningkatan seksio sesarea di RSUP Prof. Dr. R. D. Kandou Manado paling tinggi disebabkan oleh riwayat seksio sesarea sebelumnya sebanyak 107 pasien $(25,23 \%)$.

Tabel 4. Faktor ibu yang memengaruhi terjadinya seksio sesarea

\begin{tabular}{lcc}
\hline \multicolumn{1}{c}{ Faktor ibu } & Jumlah & Persentase \\
\hline Riwayat seksio & 107 & 25,23 \\
sesarea & & \\
Eklampsia /impending & 90 & 21,22 \\
eklampsia & 58 & 13,68 \\
PEB & 30 & 7,07 \\
Plasenta previa & 139 & 32,8 \\
Indikasi lain & & \\
Jumlah & 424 & 100 \\
\hline
\end{tabular}

Tabel 5 memperlihatkan bahwa indikasi janin yang memengaruhi terjadinya peningkatan seksio sesarea di RSUP Prof. Dr. R. D. Kandou Manado paling tinggi disebabkan gawat janin sebanyak 205 pasien $(54,09 \%)$.

Tabel 6 menunjukkan bahwa indikasi gabungan yang memengaruhi terjadinya peningkatan seksio sesarea di RSUP Prof. Dr. R. D. Kandou Manado paling tinggi disebabkan preeklamsi berat (PEB) dan gawat janin sebanyak 40 pasien $(21,05 \%)$.

Tabel 5. Faktor janin yang memengaruhi terjadinya seksio sesarea

\begin{tabular}{ccc}
\hline Faktor janin & Jumlah & Persentase \\
\hline Gawat janin & 205 & 54,09 \\
Kelainan letak & 93 & 24,54 \\
Makrosomia & 46 & 12,14 \\
NST Kategori 2/OCT + & 16 & 4,22 \\
Indikasi lain & 19 & 5,01 \\
Jumlah & 379 & 100 \\
\hline
\end{tabular}

Tabel 6. Faktor gabungan yang memengaruhi terjadinya seksio sesarea

\begin{tabular}{lcc}
\hline \multicolumn{1}{c}{ Faktor gabungan } & Jumlah & Persentase \\
\hline PEB dan gawat janin & 40 & 21,05 \\
KPD dan gawat janin & 17 & 8,95 \\
PEB dan makrosomia & 15 & 7,89 \\
Gagal induksi dan gawat janin & 15 & 7,89 \\
Indikasi lain & 103 & 54,22 \\
Jumlah & 190 & 100 \\
\hline
\end{tabular}


Tabel 7 menunjukkan bahwa frekuensi tertinggi yaitu indikasi multipel yang terdiri dari 2 faktor indikasi sebanyak 480 pasien $(48,34 \%)$, dan frekuensi terendah yaitu indikasi tunggal sebanyak 245 pasien $(24,67 \%)$.

Tabel 7. Distribusi menurut indikasi tunggal atau multipel

\begin{tabular}{lcc}
\hline Indikasi & Jumlah & Persentase \\
\hline Tunggal & 245 & 24,67 \\
Multipel/ganda & & \\
2 faktor & 480 & 48,34 \\
> faktor & 268 & 26,99 \\
Jumlah & 993 & 100 \\
\hline
\end{tabular}

Tabel 8 memperlihatkan bahwa frekuensi tertinggi kasus seksio sesarea ialah indikasi darurat sebanyak 931 pasien $(93,76 \%)$ dan frekuensi terendah yaitu indikasi elektif sebanyak 62 pasien $(6,24 \%)$.

Tabel 8. Distribusi frekuensi menurut tingkat kedaruratan tindakan seksio sesarea

\begin{tabular}{ccc}
\hline Indikasi & Jumlah & Persentase \\
\hline Elektif & 62 & 6,24 \\
Darurat & 931 & 93,76 \\
Jumlah & 993 & 100
\end{tabular}

\section{BAHASAN}

Berdasarkan hasil penelitian yang di lakukan di RSUP Prof. Dr. R.D. Kandou Manado didapatkan data persalinan sebanyak 2.822 kasus dan yang menjalani tindakan seksio sesarea sebanyak 1.430 $(50,67 \%)$. Hasil penelitian ini telah melampaui rekomendasi WHO yang merekomendasikan proporsi kelahiran dengan seksio sesarea sebanyak 5-15\% dinegara maju dan $21 \%$ dinegara ber-kembang dari jumlah total persalinan. Tingginya jumlah kasus seksio sesarea di RSUP Prof. Dr. R. D. Kandou Manado kemungkinan disebabkan oleh status RSUP Prof. Dr. R.D. Kandou Manado yang merupakan Rumah Sakit pusat rujukan akhir yang terletak di Sulawesi Utara. ${ }^{13}$
Karakteristik pasien dengan seksio sesarea berdasarkan usia mempelihatkan frekuensi tertinggi pada usia 21-35 tahun sebanyak 631 pasien $(63,54 \%)$. Hasil penelitian ini sejalan dengan penelitian yang dilakukan oleh Muhammad ${ }^{14}$ di RSUD Moewardi Surakarta. Pada penelitian tersebut didapatkan mayoritas pasien dengan kelompok usia 20-35 tahun sebanyak $64,4 \%$. Hasil yang didapatkan dalam penelitian ini tidak selaras dengan penelitian yang dilakukan oleh Mulyawati ${ }^{15}$ di RS Islam YAKSSI Gemolong Sragen tahun 2011, yang mendapatkan mayoritas pasien berusia $>35$ tahun sebanyak $48,3 \%$. Usia 21-35 tahun merupakan usia produktif seseorang usia 36-45 tahun ialah usia dimana mulai terjadi penurunan kesehatan dan fungsi organ reproduksi wanita; usia $<20$ tahun organ reproduksi ibu belum berkembang dengan baik; dan usia $>46$ tahun merupakan proses menopause dari seorang wanita. Usia <20 tahun dan >46 tahun termasuk dalam usia dengan risiko tinggi kehamilan. ${ }^{14,15}$

Karakteristik pasien yang menjalani seksio sesarea berdasarkan pendidikan, memperlihatkan frekuensi tertinggi yaitu SMA sebanyak 209 pasien $(21,05 \%)$. Hasil penelitian ini sesuai dengan penelitian yang dilakukan oleh Mulyawati ${ }^{15}$ di RS Islam YAKSSI Gemolong Sragen yang mendapatkan bahwa mayoritas pasien dengan pendidikan SMA sebanyak 76,6\%. Hasil penelitian ini berbeda dengan penelitian yang dilakukan oleh Yaeni $^{9}$ di RSUP Dr. Soeradji Tirtonegoro Klaten yang mendapatkan tingkat pendidikan terbanyak yaitu rendah (SD-SMP) sebesar 60\%. Pendidikan juga memengaruhi proses kehamilan dan persalinan karena semakin tinggi pendidikan seorang ibu maka pengetahuannya akan bahaya dan risiko dalam persalinan akan lebih banyak, sehingga dapat mengantisipasi dan memperkecil risiko yang dapat terjadi dalam proses persalinan. ${ }^{9,15}$

Indikasi yang berperan dalam meningkatkan seksio sesarea di RSUP Prof. Dr. R. 
D. Kandou Manado yaitu tertinggi pada indikasi ibu sebanyak 426 responden $(42,68 \%)$ yang paling banyak disebabkan oleh riwayat seksio sesarea sebelumnya berjumlah 107 pasien $(25,23 \%)$. Indikasi janin sebanyak 382 pasien $(38,28 \%)$ paling banyak disebabkan oleh gawat janin yaitu 205 pasien $(54,09 \%)$. Indikasi gabungan sebanyak 190 pasien $(19,04 \%)$ paling banyak disebabkan oleh PEB dan gawat janin yaitu 40 pasien $(21,05 \%)$. Hasil penelitian ini sesuai dengan penelitian yang dilakukan oleh Setyowati dan Nurhidayati ${ }^{16}$ di RSU PKU Muhammadiyah Yogyakarta yang menunjukkan bahwa indikasi ibu merupakan indikasi tertinggi sebesar $66,5 \%$. Hasil penelitian ini tidak sejalan dengan penelitian yang dilakukan Sumelung et a $1^{10}$ di RSUD Liun Kendage Tahuna yang mendapatkan bahwa yang paling berperan ialah indikasi janin yang disebabkan oleh gawat janin. Pada penelitian ini dapat dilihat bahwa indikasi ibu lebih banyak daripada indikasi janin dan gabungan; hal ini karena ibu berhubungan langsung dengan komponen "status reproduksi" seperti usia dan jumlah paritas atau jumlah persalinan.

Faktor ibu yang berperan meningkatkan seksio sesarea tertinggi disebabkan oleh riwayat seksio sesarea sebelumnya sebanyak 107 responden $(25,23 \%)$. Hasil penelitian ini berbeda dengan penelitian yang dilakukan oleh Setyowati dan Nurhidayati $^{16}$ di RSU PKU Muhammadiyah Yogyakarta yang melaporkan bahwa indikasi ibu tertinggi disebabkan oleh induksi persalinan gagal sebesar $20,9 \%$. Hasil penelitian ini berbeda dengan penelitian yang di lakukan oleh Muhammad ${ }^{14}$ di RSUD Moewardi Surakarta yang menunjukkan bahwa indikasi ibu tertinggi disebabkan oleh preeklampsia/eklampsia sebesar $32,2 \%$. Bekas seksio sesarea berisiko untuk terjadinya ancaman ruptur uteri yang dapat menyebabkan perdarahan. Hal lain yang dapat terjadi akibat bekas seksio sesarea yaitu plasenta previa dan abrupsio plasenta. Semakin sering dilakukannya persalinan dengan seksio sesarea maka semakin besar risiko terjadinya ruptur uteri. ${ }^{14,16}$
Faktor janin yang berperan meningkatkan seksio sesarea tertinggi di sebabkan oleh gawat janin sebanyak 205 responden (54,09\%). Hasil penelitian ini sesuai dengan penelitian yang dilakukan oleh Muhammad $^{14}$ di RSUD Moewardi Surakarta yang menunjukkan bahwa indikasi janin tertinggi disebabkan oleh gawat janin sebesar $28,7 \%$. Hasil penelitian ini berbeda dengan penelitian yang dilakukan oleh Setyowati dan Nurhidayati ${ }^{16}$ di RSU PKU Muhammadiyah Yogyakarta Tahun 2009, pada penelitian tersebut menunjukkan indikasi janin tertinggi disebabkan oleh presentasi bokong sebanyak 44,7\%. Gawat janin sering digambarkan dengan keadaan hipoksia yang merupakan hal sangat serius dan dapat membahayakan kesehatan bahkan kematian bagi janin. ${ }^{17}$

Faktor gabungan yang berperan meningkatkan seksio sesarea tertinggi disebabkan oleh PEB dan gawat janin pada sebanyak 40 pasien $(21,05 \%)$, diikuti oleh ketuban pecah dini (KPD) dan gawat janin sebanyak 17 pasien $(8,95 \%)$. Preeklamsi/ eklamsi dapat mengakibatkan terjadinya spasmus pembuluh darah. Menurunya aliran darah ke plasenta mengakibatkan terganggunya fungsi plasenta. Kurangnya aliran darah ke plasenta juga dapat mengakibatkan keadaan hipoksia yang dapat menyebabkan terjadinya gawat janin sampai kematian karena kekurangan oksigen. Berdasarkan hasil penelitian yang di lakukan oleh Sagita ${ }^{18}$ di RSUD Pringsewu, KPD merupakan salah satu faktor penyebab asfiksia dan infeksi. Komplikasi yang dapat ditimbulkan akibat KPD antara lain infeksi pada ibu dan janin yang akan di lahirkan, terjadinya prematuritas, dan respiration dystress syndrome (RDS); hal tersebut akan meningkatkan mortalitas dan morbiditas perinatal. ${ }^{18,19}$

Karakteristik pasien seksio sesarea berdasarkan indikasi tunggal dan multipel / ganda tertinggi disebabkan oleh indikasi multipel yang terdiri dari 2 faktor indikasi sebanyak 480 pasien $(48,34 \%)$. Hasil penelitian ini berbeda dengan penelitian yang dilakukan oleh Subekti ${ }^{5}$ di RSUD Panembahan Senopati Bantul yang menda- 
patkan indikasi tertinggi disebabkan oleh indikasi tunggal sebanyak 90,1\%. Indikasi tunggal ialah seksio sesarea yang disebabkan oleh satu faktor indikasi, sedangkan indikasi multipel/ganda ialah indikasi yang disebabkan oleh dua faktor atau lebih dari 2 faktor indikasi. ${ }^{5}$

Berdasarkan kondisi kegawatdaruratan frekuensi tertinggi kasus seksio sesarea ialah indikasi darurat sebanyak 931 pasien $(93,76 \%)$, dan frekuensi terendah yaitu indikasi elektif sebanyak 62 pasien $(6,24 \%)$. Hasil penelitian ini sesuai dengan penelitian yang dilakukan oleh Yaeni $^{9}$ di RSUP dr. Soeradji Tirtonegoro Klaten yang menyatakan bahwa indikasi darurat lebih banyak daripada indikasi elektif. Tingkat kegawatdaruratan pasien seksio sesarea dibedakan menjadi 2 yaitu seksio sesarea darurat dan seksio sesarea elektif. Indikasi darurat adalah tindakan persalinan dengan seksio sesarea yang dilakukan tanpa perencanaan sebelumnya, sedangkan indikasi elektif yaitu tindakan persalinan dengan seksio sesarea yang dilakukan dengan adanya perencanaan sebelumnya. Tindakan seksio sesarea merupakan suatu prosedur persalinan kedaruratan. ${ }^{9}$

\section{SIMPULAN}

Pada tindakan persalinan seksio sesarea di RSUP Prof. Dr. R.D. Kandou Manado tahun 2017 dan 2018, indikasi ibu terbanyak ialah adanya riwayat seksio sesarea, indikasi janin terbanyak ialah gawat janin, dan indikasi gabungan terbanyak ialah preeklamsi berat dan gawat janin.

Bagi peneliti lanjut disarankan untuk mengevaluasi hubungan karakteristik kehamilan dengan tindakan seksio sesarea. Bagi tenaga kesehatan di Instalasi rekam Medik RSUP Prof. Dr. R. D. Kandou diharapkan melakukan pengisian data rekam medik ataupun buku register secara lengkap dan jelas untuk memperoleh data yang lebih akurat.

\section{Konflik Kepentingan}

Penulis menyatakan tidak terdapat konflik kepentingan dalam studi ini.

\section{DAFTAR PUSTAKA}

1. Profil Kesehatan Indonesia tahun 2017. Jakarta: Kementerian Kesehatan RI, 2018.

2. Infodatin: Pusat Data dan Informasi Kementerian Kesehatan RI. Jakarta Selatan, 2014.

3. Rencana Strategi Kementerian Kesehatan 2015-2019. Keputusan Menteri Kesehatan Republik Indonesia Nomor HK.02.02/MENKES/52/2015. Jakarta: Kementerian Kesehatan RI, 2015.

4. Maternal mortality. WHO, 16 February 2018. [cited 2019 Aug 20]. Available from:https://www.who.int/news-room/ fact-sheets/detail/maternal-mortality

5. Subekti SW. Indikasi persalinan seksio sesarea. Jurnal Biometrika dan Kependudukan, 2018;7(1):11-9.

6. Kurniarum A. Asuhan Kebidanan Persalinan dan Bayi Baru Lahir. Jakarta Selatan: Kementerian Kesehatan Republik Indonesia, 2016.

7. Ayuningtyas D, Oktarina R, Misnaniarti, Sutrisnawati NNI. Etika kesehatan pada persalinan melalui sectio caesareatanpa indikasi medis. Jurnal MKMI, 2018; 14(1):9-16.

8. Cunningham FG, Gant NF. Seksio Sesarea. In: Dasar-dasar Ginokologi \& Obstetri. Jakarta: EGC, 2010; p. 404-70.

9. Yaeni M. Analisa indikasi dilakukan persalinan sectio caesarea di RSUP Dr. Soeradji Tirtonegoro Klaten [Skripsi]. Surakarta: Universitas Muhammadiyah Surakarta; 2013.

10. Sumelung V, Kundre R, Karundeng M. Faktor-faktor yang berperan mening katnya angka kejadian sectio caesarea di Rumah Sakit Umum Daerah Liun Kendage Tahuna. Manado: Ejournal Keperawatan, 2014;2(1):1-7.

11. Andriani D. Factor-faktor yang mempe ngaruhi tindakan seksio sesarea di Rumah Sakit Umum Daerah Kabu paten Dompu Tahun 2010 [Skripsi]. Depok: Universitas Indonesia; 2012.

12. Cunningham FG, Gant NF. Pelahiran caesar dan histerektomi peripartum. In: Obs tetri Williams Vol. 1 (23th ed). Jakarta: EGC, 2012; p. 568-90.

13. Sihombing N, Saptarini I, Putri DSK. Determinan Persalinan Sectio Caesarea di Indonesia (Analisis Lanjut Data Riskesdas 2013). Pusat Penelitian Dan 
Pengembangan Upaya Kesehatan Masyarakat. Jakarta: Badan Litbang Kesehatan, 2017.

14. Muhammad R. Karakteristik ibu yang mengalami persalinan dengan sectio caesarea di Rumah Sakit Umum Daerah Moewardi Surakarta Tahun 2014 [Skripsi]. Surakarta: Universitas Muhammadiyah Surakarta; 2016.

15. Mulyawati I. Faktor-faktor yang berhubungan dengan persalinan operasi seksio sesarea di Rumah Sakit Islam Yakssi Gemolong Kabupaten Sragen Tahun 2010 [Skripsi]. Sragen: Universitas Negeri Semarang; 2011.

16. Setyowati D, Nurhidayati E. Faktor-faktor yang mempengaruhi terjadinya seksio sesarea pada ibu bersalin di RSU PKU Muhammadiyah Yogyakarta tahun 2009. Yogyakarta: STIKES 'Aisyiyah Yogyakarta; 2009.
17. Andayasari L, Muljati S, Sihombing M, Arlinda D, Opitasari C, Mogsa DF, et al. Proporsi seksio sesarea dan faktor yang berhubungan dengan seksio sesarea di Jakarta. Buletin Penelitian Kesehatan. 2015;43(2):105-16.

18. Sagita YD. Hubungan antara ketuban pecah dini dan persalinan sectio caesarea dengan kejadian asfiksia pada bayi baru lahir. Lampung: STIKES Aisyah Pringsewu Lampung. Di akses melalui: https://media.neliti.com/media/publicati ons/195284-ID-hubungan-antaraketuban-pecah-dini-dan-p.pdf

19. Saputra AN. Hubungan Antara Preeklampsia Berat Dan Kelahiran Prematur Di Rumah Sakit Dr. Oen Surakarta Periode 2014-2015[Skripsi]. Surakarta: Universitas Muhammadiyah Sukarta, 2017. 